\title{
Short communication: Test of the relationship between prepartum milk leakage and blood calcium concentration in Holstein cows-An observational study
}

\author{
Ehsan Mahjoubi, ${ }^{, 1}$ Davood Zahmatkesh, ${ }^{*}$ Mehdi Hossein-Yazdi, $†$ Mohammad Hadi Khabbazan, ${ }^{*}$ \\ and Mohammad Reza Samadianł \\ *Department of Animal Science, University of Zanjan, Zanjan, Iran 45371-38791 \\ †Department of Animal Science, Arak University, Arak, Iran 38156-88349 \\ ‡Qiam Dairy Complex, Isfahan, Iran 83145-46611
}

\begin{abstract}
Prepartum milk leakage happens in some pregnant dairy cows close to calving. It has been hypothesized that low blood $\mathrm{Ca}$ is a cause of this event. To investigate the possible reason(s) of milk leakage, 137 multiparous pregnant Holstein cows were enrolled in the experiment and categorized by the presence (72 cows; leak group) or lack (65 cows; control group) of milk leakage before calving. The concentrations of $\mathrm{Ca}$ and $\mathrm{P}$ and the length of the teat were measured for all cows. Data showed that $\mathrm{Ca}$ concentration was not different between cows in the leak group $(7.90 \mathrm{mg} / \mathrm{dL})$ and those in the control group $(7.99 \mathrm{mg} / \mathrm{dL})$. Moreover, neither $\mathrm{P}$ concentration ( 4.62 vs. $4.54 \mathrm{mg} / \mathrm{dL})$ nor teat length $(4.28$ vs $4.10 \mathrm{~cm})$ differed between leak and control groups. Milk yield was greater for the leak group $(53.6 \mathrm{~kg} / \mathrm{d})$ compared with the control group $(50.1 \mathrm{~kg} / \mathrm{d})$ through $4 \mathrm{mo}$ in milk. The leakage did not affect the odds of postpartum disorders such as retained placenta, metritis, mastitis, displaced abomasum, or lameness occurrence. The current results show that hypocalcemia is not a reason for observed prepartum leakage and that cows in the leak group produced more milk in the subsequent lactation period.
\end{abstract}

Key words: mammary gland, milk leakage, prepartum calcium level

\section{Short Communication}

Milk leakage (ML) or milk dripping is defined as a condition in which milk loss happens through the teat end not related to milking. Milk leakage is important as it has been linked to mastitis in several studies (Schukken et al., 1993; Elbers et al., 1998; Waage et al., 2001).

Received August 30, 2017

Accepted December 13, 2017.

${ }^{1}$ Corresponding author: e_mahjoubi@znu.ac.ir
Persson Waller et al. (2003) found no relationship between ML and milk production, parity, stage of lactation, or estrus status. Klaas et al. (2005) indicated that high peak milk flow rate, short teats, teat canal protrusion, inverted teat ends, and early lactation increased the risk of ML in multiparous cows. To our knowledge, there is no information about ML just before calving. Waage et al. (2001) reported ML in heifers around the time of parturition as a risk factor of mastitis, but the cause of this ML was not determined. Because ML in dairy cows is a symptom of impaired function of the teat sphincter (Klaas et al., 2005), it is believed that Ca deficiency can affect this disorder; smooth muscle contraction, including teat sphincter smooth muscle, is dependent in part on the Ca concentration in the cytosol (Constable et al., 2012; Goff, 2014). Therefore, the objective of this observational study was to investigate the possible relationship of prepartum ML with Ca and $\mathrm{P}$ concentrations and its effect on the subsequent milk yield and disorders such as hypocalcemia. We hypothesized that a low plasma Ca can lead cows to have more leakage during the prepartum period.

The study was carried out from January to March 2017 in the Qiam Dairy Complex (Qiam Animal Husbandry and Agriculture Co., Isfahan, Iran) that houses 4,400 dairy cows of the Holstein breed with an average daily production of $42 \mathrm{~kg} /$ lactating cow. A total of 137 multiparous Holstein cows were enrolled in this study.

When milk leaked (any ML from teats before calving) from a dry cow (leak group; $72 / 137$ cows), a blood sample was taken and teat length was measured. Visual inspection of close-up cows during the routine daily monitoring, every 2 to $3 \mathrm{~h}$, was used to detect any ML from the lying cows with the milk dropping from the teat on the floor. Blood was taken from the coccygeal vein using an evacuated tube without anticoagulant (Vacumed no additive; FL Medical, Torreglia, Italy). Serum samples were taken following centrifugation at $2,500 \times g$ for $10 \mathrm{~min}$ and were stored at $-20^{\circ} \mathrm{C}$ for 
later analysis. After thawing, the serum was analyzed for concentrations of $\mathrm{Ca}$ (colorimetric cresolphthalein complexone method; Darman Faraz Kave, Tehran, Iran) and $\mathrm{P}$ (colorimetric molybdate method; ZiestChem Diagnostics, Tehran, Iran). At the same time, a similar cow was selected based on the expected calving time and the symptom of calving without ML (control group), and the same measurements were carried out. After parturition, ketosis was diagnosed by blood sampling daily throughout the 10 DIM using the blood $\beta$-ketone strips (FreeStyle; Abbott Diabetes Care, Doncaster, Australia). Milk yield was recorded monthly by the regular program of the dairy farm so that the milk yield at each shift at 0700,1500 , and $2300 \mathrm{~h}$ was recorded and total milk yield was calculated.

Disorders were defined as follows: retained placenta as placenta not expelled by $24 \mathrm{~h}$; ketosis as the blood ketone bodies $\geq 1.2 \mathrm{mmol} / \mathrm{dL}$; displaced abomasum as the presence of a pinging noise that sounds like a tap dripping into a steel bucket by listening over the abdomen with a stethoscope; mastitis as the presence of coagulant during the predipping process in the milking parlor; metritis as the presence of fetid red-brown watery uterine discharge at 5 to 20 DIM; lameness as cows with a locomotion score of $\geq 4$ on a 5 -point scale (Sprecher et al., 1997); and milk fever as cows in headdown recumbency with paresis after parturition that responded to intravenous $\mathrm{Ca}$.

All statistical analyses were carried out with SAS (version 9.4; SAS Institute Inc., Cary, NC). Serum mineral concentrations and teat length were analyzed with cow as the subject using PROC GLM of SAS (Littell et al., 2006). Milk yield was analyzed as repeated measures using PROC MIXED of SAS (Littell et al., 2006). Data from diseases (retained placenta, displaced abomasum, metritis, mastitis, milk fever, and ketosis) were analyzed with PROC GENMOD with binomial distributions. For each binary variable, ML status at precalving (leak vs. control) was offered as a covariate. A logistic regression model for ML was calculated using the GENMOD procedure with generalized estimating equations (Liang and Zeger, 1986) with compound of symmetry covariance structure (Dohoo et al., 2003) using binomial distribution. The logistic regression model included the fixed effects of treatment.

Data are reported as least squares means. Statistical significance was declared at $P \leq 0.05$, and $0.05<P \leq$ 0.10 was considered a trend toward significance using Tukey's multiple comparison test.

The prepartum serum concentrations of $\mathrm{Ca}$ and $\mathrm{P}$, teat length, and milk yield are presented in Table 1 . The average day when ML was diagnosed and blood samples were obtained was $1.4 \pm 0.9 \mathrm{~d}$ before calving (mean $\pm \mathrm{SD}$ ). In contrast with our hypothesis, there was no difference in Ca concentration $(P=0.70)$ between leak and control cows. According to Oetzel and Eastridge (2013), who defined postpartum hypocalcemia as serum Ca concentration $\leq 8.5 \mathrm{mg} / \mathrm{dL}$, all cows (leak and control groups) were hypocalcemic during the prepartum period. It should be kept in mind that Oetzel and Eastridge (2013) defined this cut point for postcalving cows (not precalving cows). Although it is believed that hypocalcemia reduces the contraction of the teat sphincter muscle responsible for closure of the teat orifice (Goff, 2014), the current data show that precalving $\mathrm{Ca}$ concentration is not a causative factor for ML. We are not aware of any data in which prepartum $\mathrm{Ca}$ is $<8.5 \mathrm{mg} / \mathrm{dL}$ and to what extent this low $\mathrm{Ca}$ concentration can affect cow performance. More recently, Neves et al. (2017) showed that multiparous cows with Ca concentrations $\leq 9.6 \mathrm{mg} / \mathrm{dL}$ (too far from the achieved values in the current study) in the prepartum period and cows in third or greater parity had a higher risk of being categorized as subclinical hypocalcemic at calving. Neves et al. (2017) defined this value as a cut point for prepartum animals that are more prone to be hypocalcemic after calving. Because the average days to calving in 2 groups was $1.4 \pm 0.9$, low Ca concentration was partly anticipated as reported by Moore et al. (2000), who showed that Ca level is slightly lesser when a cow is close to parturition. Acidogenic diets are hypothesized to increase serum Ca by increasing $\mathrm{Ca}$ mobilization from bone, as indicated by elevated serum hydroxyproline (Goff et al., 1991). Despite the fact that the cows enrolled in the current study were fed an anionic diet, Ca level was below the defined threshold for hypocalcemia. Green et al. (1981) also reported a prepartum Ca level of close to $8 \mathrm{mg} / \mathrm{dL}$ at $-1 \mathrm{~d}$ to calving for cows fed a high-Ca diet. Moreover, $\mathrm{P}$ concentration did not differ across treatments $(P=0.62)$. Serum $P$ is closely associated with serum Ca concentration because both make up the hydroxyapatite lattice structure of bone. Because serum Ca did not differ with treatment, serum $\mathrm{P}$ was expected to be similar.

Table 1. Average daily milk yield (first 4 mo of lactation), serum Ca and $\mathrm{P}$ concentrations at the time milk leakage was diagnosed, and teat length in cows without milk leakage (Control) or with milk leakage (Leak)

\begin{tabular}{lcccc}
\hline & \multicolumn{2}{c}{ Treatment } & & \\
\cline { 2 - 3 } Item & Control & Leak & & \\
& SEM & P-value \\
\hline Milk, kg & 50.15 & 53.63 & 1.24 & 0.04 \\
Calcium, mg/dL & 7.99 & 7.91 & 0.15 & 0.70 \\
Phosphorus, mg/dL & 4.54 & 4.62 & 0.12 & 0.62 \\
Teat length, cm & 4.30 & 4.280 & 0.14 & 0.93 \\
\hline
\end{tabular}


Table 2. Summary of binary logistic regression model of the effect of milk leakage (Leak) or absence of milk leakage (Control) on postpartum disorders

\begin{tabular}{|c|c|c|c|c|c|}
\hline Item & $\begin{array}{c}\text { Incidence, } \\
\%\end{array}$ & Estimate & $\begin{array}{c}\text { Relative risk } \\
\quad(95 \% \mathrm{CI})\end{array}$ & SEM & $P$-value \\
\hline \multicolumn{6}{|c|}{ Displaced abomasum } \\
\hline Control & 3.33 & & & & \\
\hline Leak & 2.82 & 0.02 & $1.17(0.16-8.59)$ & 0.51 & 0.88 \\
\hline \multicolumn{6}{|l|}{ Ketosis } \\
\hline Control & 1.67 & & & & \\
\hline Leak & 4.23 & 0.69 & $0.38(0.04-3.74)$ & 0.58 & 0.41 \\
\hline \multicolumn{6}{|l|}{ Lameness } \\
\hline Control & 5.0 & & & & \\
\hline Leak & 5.63 & 0.03 & $0.87(0.19-4.04)$ & 0.39 & 0.86 \\
\hline \multicolumn{6}{|l|}{ Mastitis } \\
\hline Control & 16.67 & & & & \\
\hline Leak & 19.72 & 0.24 & $0.80(0.33-1.96)$ & 0.23 & 0.63 \\
\hline \multicolumn{6}{|l|}{ Metritis } \\
\hline Control & 25.0 & & & & \\
\hline Leak & 22.54 & 0.08 & $1.12(0.50-2.52)$ & 0.21 & 0.77 \\
\hline \multicolumn{6}{|l|}{ Milk fever } \\
\hline Control & 3.33 & & & & \\
\hline Leak & 1.41 & 0.49 & $2.38(0.21-26.91)$ & 0.62 & 0.48 \\
\hline \multicolumn{6}{|c|}{ Retained placenta } \\
\hline Control & 15.0 & & & & \\
\hline Leak & 19.72 & 0.55 & $0.71(0.28-1.77)$ & 0.23 & 0.46 \\
\hline
\end{tabular}

Teat length was not different between treatments $(P$ $>0.93)$. Klaas et al. (2005), in an attempt to assess whether teat shape, condition of teat orifice, and peak milk flow rate are risk factors for ML, found the short teat as a causative factor in ML in multiparous, but not primiparous, cows. More interestingly, a short teat was categorized as teat length $<4.5 \mathrm{~cm}$, which is too far from the observed teat length in the current study. Short teats may have had shorter teat canals, resulting in an impaired sphincter muscle function when intramammary pressure before milking is elevated (Klaas et al., 2005). The current study provides some evidence that the prepartum ML has a different mechanism regardless of teat shape.

As shown in Table 2, no correlation was found between ML status prepartum and any of the postpartum disorders that were included in this study. However, these data should be interpreted with caution because of the relatively small sample size for some diseases such as mastitis. Waage et al. (2001) indicated that ML at calving is a risk factor for clinical mastitis caused by Staphylococcus aureus in heifers, where they evaluated 364 case-control pairs from 306 different herds. However, the current study did not realize any relationship between prepartum ML and postpartum mastitis; it is probably because they evaluated the heifers in their study compared with mature cows in the current experiment. Nonetheless, Waage et al. (2001) concluded that ML might have been, to some extent, a consequence of udder and teat edema.
In conclusion, the current observational experiment provides some evidence that prepartum plasma $\mathrm{Ca}$ and $\mathrm{P}$ concentrations have no effect on prepartum ML. Moreover, there was no relation between prepartum ML and postpartum metabolic disorders under the conditions of this study and with the small sample size.

\section{ACKNOWLEDGMENTS}

The authors express their gratitude to the Pars Holding Co. (Tehran, Iran) and the Qiam Animal Husbandry and Agriculture Co. (Isfahan, Iran) for allowing access to their cows and facilities.

\section{REFERENCES}

Constable, P. D., M. Nouri, I. Sen, A. N. Baird, and T. Wittek. 2012. Evidence-based use of prokinetic drugs for abomasal disorders in cattle. Vet. Clin. North Am. Food Anim. Pract. 28:51-70. https:// doi.org/10.1016/j.cvfa.2011.12.008.

Dohoo, I. R., W. Martin, and H. Stryhn. 2003. Veterinary Epidemiologic Research. AVC Inc., Charlottetown, Prince Edward Island, Canada.

Elbers, A. R. W., J. D. Miltenburg, D. De Lange, A. P. P. Crauwels, H. W. Barkema, and Y. K. Schukken. 1998. Risk factors for clinical mastitis in a random sample of dairy herds from the southern part of Netherlands. J. Dairy Sci. 81:420-426. https://doi.org/10.3168/ jds.S0022-0302(98)75592-4.

Goff, J. P. 2014. Calcium and magnesium disorders. Vet. Clin. North Am. Food Anim. Pract. 30:359-381. https://doi.org/10.1016/j .cvfa.2014.04.003.

Goff, J. P., R. L. Horst, F. J. Mueller, J. K. Miller, G. A. Kiess, and H. H. Dowlen. 1991. Addition of chloride to a prepartal diet high in cations increases 1, 25-dihydroxyvitamin D response to hypocalce- 
mia preventing milk fever. J. Dairy Sci. 74:3863-3871. https://doi .org/10.3168/jds.S0022-0302(91)78579-2.

Green, H. B., R. L. Horst, D. C. Beitz, and E. T. Littledike. 1981. Vitamin D metabolites in plasma of cows fed a prepartum low-calcium diet for prevention of parturient hypocalcemia. J. Dairy Sci. 64:217-226. https://doi.org/10.3168/jds.S0022-0302(81)82557-X.

Klaas, I. C., C. Enevoldsen, A. K. Ersboll, and U. Tölle. 2005. Cow related risk factors for milk leakage. J. Dairy Sci. 88:128-136. https://doi.org/10.3168/jds.S0022-0302(05)72670-9.

Liang, K. Y., and S. L. Zeger. 1986. Longitudinal data analysis using generalized linear models. Biometrika 73:13-22. https://doi.org/10 .1093/biomet/73.1.13.

Littell, R. C., G. A. Milliken, W. W. Stroup, R. D. Wolfinger, and O. Schabenberger. 2006. SAS for Mixed Models. 2nd ed. SAS Institute Inc., Cary, NC.

Moore, S. J., M. J. Vandehaar, K. Sharma, T. F. Pilbcam, D. K Beede, F. Bucholtz, J. S. Liesman, R. L. Horst, and J. P. Goff 2000. Effect of altering dietary cation-anion difference on calcium and energy metabolism in peripartum cows. J. Dairy Sci. 83:20952104. https://doi.org/10.3168/jds.S0022-0302(00)75091-0.

Neves, R. C., B. M. Leno, T. Stokol, T. R. Overton, and J. A. A McArt. 2017. Risk factors associated with postpartum subclinical hypocalcemia in dairy cows. J. Dairy Sci. 100:3796-3804. https:// doi.org/10.3168/jds.2016-11970.

Oetzel, G. R., and M. Eastridge. 2013. Minimizing hypocalcemia during early lactation. Pages 23-34 in Proc. 22nd Tri-State Dairy Nutrition Conference, Fort Wayne, IN. Michigan State University, East Lansing.

Persson Waller, K., T. Westermark, T. Ekman, and K. SvennerstenSjaunja. 2003. Milk leakage-An increased risk in automatic milking systems. J. Dairy Sci. 86:3488-3497. https://doi.org/10.3168/ jds.S0022-0302(03)73953-8.

Schukken, Y. H., J. Vanvliet, D. Van de Geer, and F. J. Grommers. 1993. A randomized blind trial on dry cow antibiotic infusion in a low somatic cell count herd. J. Dairy Sci. 76:2925-2930. https:// doi.org/10.3168/jds.S0022-0302(93)77632-8.

Sprecher, D. J., D. E. Hostetler, and J. B. Kaneene. 1997. A lameness scoring system that uses posture and gait to predict dairy cattle reproductive performance. Theriogenology 47:1179-1187. https:// doi.org/10.1016/S0093-691X(97)00098-8.

Waage, S., S. A. Odegaard, A. Lund, S. Brattgjerd, and T. Rothe. 2001. Case-control study of risk factors for clinical mastitis in postpartum dairy heifers. J. Dairy Sci. 84:392-399. https://doi.org/10 $.3168 /$ jds.S0022-0302(01)74489-X. 